\title{
Studying human airway pharmacology in microsections: application of videomicrometry
}

\author{
D.T. Schmidt*, G. Dent", E. Rühlmann*, N.M. Muñoz", A.R. Leff", K.F. Rabe*
}

Studying human airway pharmacology in microsections: application of videomicrometry. D.T. Schmidt, G. Dent, E. Rühlmann, N.M. Muñoz, A.R. Leff, K.F. Rabe. (C)ERS Journals Ltd 2002.

ABSTRACT: The influence of endogenously-released mediators and activated eosinophils on the airway lumen and the effect of passive sensitization on anti-immunoglobulin (Ig)-E-induced contractile responses was investigated by videomicrometry.

Human bronchial sections of 2-3 mm internal diameter, placed in $250 \mu \mathrm{L}$ Hank's balanced salt solution on microtitre plates, were monitored and recorded by digitized image analysis. Airway preparations exhibited a spontaneous narrowing (mean \pm SEM $-33 \pm 5 \%$ of the luminal area). Removal of the bronchial epithelium almost completely prevented the development of spontaneuous narrowing $(-6 \pm 3 \%$; $\mathbf{p}<\mathbf{0 . 0 0 1})$. The addition of platelet-activating factor stimulated human eosinophils to the bronchial sections led to significant narrowing of the airway lumen $(-39 \pm 9 \% ; \mathbf{p}<0.05)$. Passive sensitization induced hyperresponsiveness to polyclonal anti-IgE $(-35 \pm 8 \%$; $\mathbf{p}<\mathbf{0 . 0 1 )}$.

It is concluded that videomicrometry is suitable for studying interactions between human airways and inflammatory cells, as well as the effect of passive sensitization on smooth muscle reactivity in vitro, without the imposition of preload. Under these conditions, human airways exhibited a spontaneous decrease of the airway lumen over time suggesting a role for epithelium-derived mediators because the development of spontaneous tone was epithelium dependent.

Eur Respir J 2002; 19: 991-996.
*Leiden University Medical Centre, Dept of Pulmonology, Leiden, the Netherlands. " University of Southampton School of Medicine, Respiratory Cell and Molecular Biology Section, Division of Infection, Inflammation and Repair, Southampton, UK. "University of Chicago, Section of Pulmonary and Critical Care Medicine and Committee on Cell Physiology and Clinical Pharmacology, Chicago, IL, USA.

Correspondence: K.F. Rabe, Leiden University Medical Centre, Dept of Pulmonology, C3-P, P.O. Box 9600, NL-2300 RC Leiden, The Netherlands. Fax: 31715266927

E-mail: K.F.Rabe@lumc.nl

Keywords: Bronchi, epithelium, eosinophils, immunological sensitization, smooth muscle, video microscopy

Received: June 282001

Accepted after revision January 132002

This work was funded by grants from the German Ministry for Research and Technology (BMFT 01 KE 9301) and the National Institutes of Health (HL-46368, SCOR HL-56399, NIAID V01-AI-34566).
Studies of the responsiveness of airway smooth muscle are important for developing understanding of the mechanisms involved in bronchoconstriction in conditions such as bronchial asthma. Airway responses can be studied in vitro in organ baths under isometric conditions, in which a resting tension is imposed on the tissues and changes in the force exerted by the muscle against this tension are measured [1], or isotonic conditions, in which a fixed force is imposed on the tissue and the changes in its length are measured [2]. However, airway smooth muscle contraction in vivo is neither isometric nor isotonic, but rather auxotonic, i.e. contraction under elastic or visco-elastic loads resulting from the attachment of the smooth muscle to adjacent structures by tissues of variable compliance. Furthermore, experiments under isometric and isotonic conditions are routinely conducted in organ baths of relatively large volumes, which results in an extensive dilution of endogenous factors and confers a requirement for large quantities of pharmacological substances or biological stimuli such as isolated cells.
A miniaturized system has been developed to monitor changes in the luminal area of isolated airway preparations directly in real time with the use of computerized videomicrometry [3]. This technique allows for the determination of constriction and dilation of airways in a very small incubation volume under quasi-auxotonic conditions [4].

Airflow limitation through a reduction of the airway lumen under baseline conditions and through exaggerated airway narrowing in response to bronchospasmogenic stimuli are important features of asthma and are believed to result from, among other factors, eosinophilic airway inflammation and sensitizationinduced alterations of smooth muscle function. Since airway tone is regulated by complex interaction of locally-produced mediators from various inflammatory cells, some of which are believed to play an important role in asthma [5, 6], large incubation volumes in organ baths might inadequately reflect the physiological state owing to extreme dilution of these endogenous factors. Therefore, the present authors investigated the influence of endogenously-released 
mediators and activated eosinophils on the airway lumen in addition to the effect of passive sensitization on anti-immunoglobulin (Ig)-E-induced contractile responses in a low-volume system using videomicrometry.

\section{Material and methods}

\section{Airway preparation}

Lung resection material was obtained from patients undergoing thoracic surgery for cancer. Macroscopically normal airways with an internal diameter of $2-3 \mathrm{~mm}$, free of alveolar tissue, were dissected and placed in oxygenated $(95 \%$ oxygen, $5 \%$ carbon dioxide) modified Krebs buffer ( $\mathrm{pH} 7.4$; composition in $\mathrm{mM}: \mathrm{NaCl} 118.4, \mathrm{KCl} 4.7, \mathrm{MgSO}_{4} 0.6, \mathrm{CaCl}_{2}$ 1.3, $\mathrm{KH}_{2} \mathrm{PO}_{4} 1.2, \mathrm{NaHCO}_{3} 25.0$, glucose 11.1). The airway preparations were kept at $4^{\circ} \mathrm{C}$ in oxygenated Krebs and used the next day.

\section{Eosinophil isolation}

Eosinophils were isolated from the peripheral blood of atopic, nonasthmatic donors as described previously [7]. Cell preparations contained $92 \pm 1 \%$ eosinophils (mean \pm SEM, $\mathrm{n}=11$ preparations from 10 donors).

\section{Eosinophil activation assay}

To confirm eosinophil stimulation by plateletactivating factor (PAF (1-O-hexadecyl-2-acetyl-snglycero-3-phosphocholine); Calbiochem-Novabiochem $\mathrm{GmbH}$, Bad Soden, Germany), superoxide anion $\left(\mathrm{O}_{2} \cdot^{-}\right)$generation was measured as the superoxide dismutase (SOD; from bovine erythrocytes)-inhibited reduction of cytochrome $\mathrm{c}$ (from horse heart), essentially as described in [7]. Reaction mixtures containing eosinophils, ferricytochrome $\mathrm{c}$ and PAF $(1 \mu \mathrm{M})$ or control buffer were incubated at $37^{\circ} \mathrm{C}$. Aliquots $(225 \mu \mathrm{L})$ were withdrawn at 5, 10, 15,

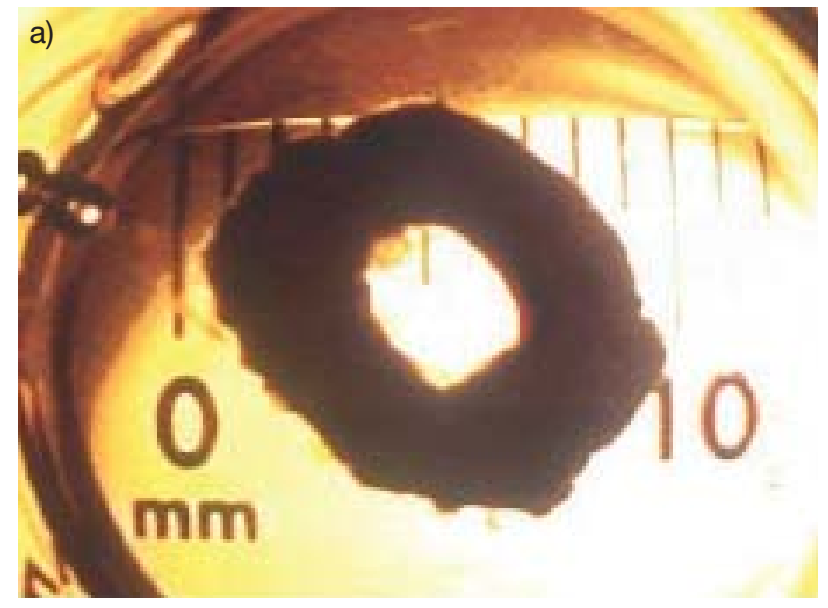

30 and $45 \mathrm{~min}$. Cells were precipitated by centrifugation $(12,000 \times g$ for $2 \mathrm{~min})$ and the extinction of $200-\mu \mathrm{L}$ portions of the supernatants was measured at $550 \mathrm{~nm}$ in a 96-well microplate reader. Cytochrome c reduction was calculated from the increase in extinction compared to a control sample to which SOD $\left(30 \mathrm{U} \cdot \mathrm{mL}^{-1}\right)$ was added immediately before the stimulus. Results are expressed as nmol cytochrome c reduced per $10^{6}$ cells in $15 \mathrm{~min}$, based on a molar extinction coefficient for ferrocytochrome $\mathrm{c}$ of $21.1 \times 10^{3} \mathrm{M}^{-1} \cdot \mathrm{cm}^{-1}$.

\section{Passive sensitization}

Bronchial rings were incubated overnight in tubes containing modified Krebs buffer in the presence (passively sensitized) or absence (nonsensitized controls) of IgE-rich serum (10\% vol/vol), as described previously [8].

\section{Videomicroscopy}

Isolated airways were cut into rings $\sim 1-2 \mathrm{~mm}$ thick and placed in $10-\mathrm{mL}$ organ baths containing Hanks balanced salt solution (HBSS (Gibco-BRL, Eggenstein, Germany), $\mathrm{pH} 7.4$ at $37^{\circ} \mathrm{C}$ ) for $\geqslant 60$ min before being transferred to microtitre plate wells containing HBSS $\left(37^{\circ} \mathrm{C}\right)$. Tissues were washed three times and then transferred to wells containing $250 \mu \mathrm{L}$ HBSS (fig. 1).

A cross-sectional image was captured $15 \mathrm{~min}$ later using a Leica Stereozoom 6 photomicroscope (Leica Microsystems Inc., Allendale, NJ, USA) and a Hitachi KP-501 colour video camera transmitting images to a Panasonic AG1970 video recorder, which was connected to a personal computer equipped with a TrueVision Targa+ 16/32 video digitizing board (Truevision, IN, USA). Between subsequent recordings, wells were covered with sealing film to prevent evaporation of buffer.

A constant fluid volume is critical to capture images adequately, because the meniscus of the buffer surface

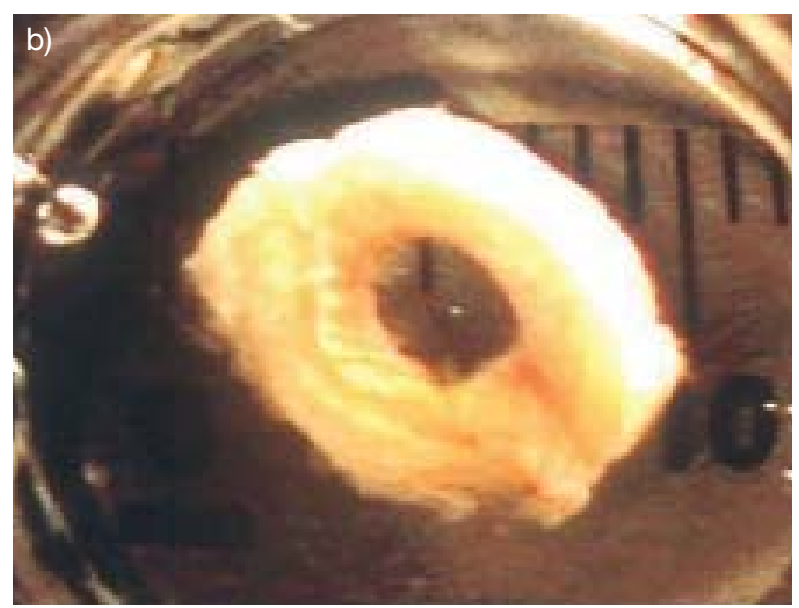

Fig. 1.-a) Microscopic image of a trans-illimunated section of a bronchial ring. b) Image of a cis-illuminated section of a bronchial ring. The area of the airway lumen can be determined by videomicrometry. 
in the microwells acts as a magnifying lens whose focus will change with changes in the volume. Therefore, preliminary experiments were performed to determine the significance of evaporation from the microwells and its possible effect on the time/course of changes in the luminal area of airway preparations. For this purpose, the cross-sectional luminal area of a metal ring and airway sections were recorded in parallel for a time period of $\leqslant 90 \mathrm{~min}$. The metal ring and tissue samples were equally and fully submerged with buffer during measurements.

Time points of the recordings were based on the findings of these initial studies. The time/course of all changes in the luminal area after a single dose of a drug, vehicle or cells (time/course experiments) or the effect of increasing concentrations of a drug (concentration/effect experiments) were recorded. For both types of experiment, a reference image for the calculation of pixel numbers (time 0) was captured $15 \mathrm{~min}$ after the first image (see earlier). For time/ course experiments, the drug, vehicle or cells were applied to the tissues immediately thereafter. The images were captured at 5-15 min intervals for $45 \mathrm{~min}$ (time $5,10,15,20,30$, and $45 \mathrm{~min}$ ). Concentration/ effect curves to anti-IgE within a range of $10^{-9}$ $10^{-5} \mathrm{mg} \cdot \mathrm{mL}^{-1}$ were constructed in a cumulative manner by adding increasing concentrations at log intervals every $10 \mathrm{~min}$.

Since changes in fluid volume cause a change in the magnification of images, the total volume was kept constant in the microwell by removing a volume equal to that subsequently applied before the addition of drugs and eosinophils [3]. A control tissue was always run in parallel to determine spontaneous changes in cross-sectional area with time. These tissues (time controls) received buffer after the initial 15-min equilibration period, when the other tissues received drug or cells. At the end of each individual experiment, tissue viability was confirmed by the addition of $10 \mu \mathrm{M}$ carbachol (Sigma Chemicals, Disenhofen, Germany) or $1 \mu \mathrm{M}$ isoprenaline (Sigma Chemicals) to induce contraction or relaxation, respectively.

In some experiments the epithelium of the airways was removed mechanically by rubbing the luminal surface of the preparations with a dampened pipe cleaner before they were cut into rings. After completion of the experiments, epithelial-denuded preparations were preserved for histological assessment of epithelial integrity.

\section{Measurement and analysis of results}

Images of the preparations obtained through the videomicrometry system were recorded on videotape, as described previously [3], and changes in crosssectional area were determined in pixel numbers using image analysis software (Mocha ${ }^{\mathrm{TM}} / \operatorname{SigmaScan}(\mathbb{R})$ Pro, SPPS Science ${ }^{\mathrm{TM}}$, Chicago, IL, USA). The percentage of airway narrowing was expressed as the change in the luminal cross-sectional area from the area recorded immediately before addition of the drug (time 0), i.e. after the 15-min microwell equilibration period.

All values are expressed as mean \pm SEM from the indicated number of experiments using tissue from different individuals. Statistical analysis of the data of the time/course experiments was performed using paired or unpaired t-tests. A $\mathrm{p}<0.05$ was considered significant.

Lyophilized PAF was dissolved, to give a concentration of $1 \mathrm{mM}$, in deionized water 15-30 min before use and diluted to the desired concentration in HEPES buffer (HEPES, $20 \mathrm{mM}$; NaCl, $132 \mathrm{mM}$; $\mathrm{KCl}, 6 \mathrm{mM} ; \mathrm{KH}_{2} \mathrm{PO}_{4}, 1.2 \mathrm{mM} ; \mathrm{Mg}_{2} \mathrm{SO}_{4}, 1.0 \mathrm{mM}$; $\mathrm{CaCl}_{2}, 1.0 \mathrm{mM}$; D-glucose, $5.5 \mathrm{mM}$; BSA (fraction V powder), 0.25\% w/v; pH 7.4). Carbachol, histamine (Sigma Chemicals), isoprenaline and polyclonal antiIgE (Sigma Chemicals) were dissolved and diluted in normal saline immediately before use.

\section{Results}

\section{Changes in cross-sectional area with time}

Data obtained on five separate occasions from the recordings of a metal ring demonstrated that the measurements of the cross-sectional area were not significantly influenced by evaporation over a time period of $60 \mathrm{~min}$ (fig. 2). Loss of reaction buffer during $1 \mathrm{~h}$ was $8.7 \pm 0.4 \mu \mathrm{L} \cdot$ well $^{-1}, 3.5 \%$ of the total volume.

Epithelium-intact human bronchial rings consistently exhibited a spontaneous luminal narrowing after an initial equilibration of $\sim 15$ min over a time period of $60 \mathrm{~min}$ (fig. 3). Indomethacin $(1 \mu \mathrm{M})$ had no effect on spontaneous luminal narrowing of epitheliumintact bronchial rings (data not shown).

\section{Effect of epithelium removal on spontaneous luminal narrowing}

Compared to epithelium-intact bronchial rings spontaneous luminal narrowing of epithelium-denuded

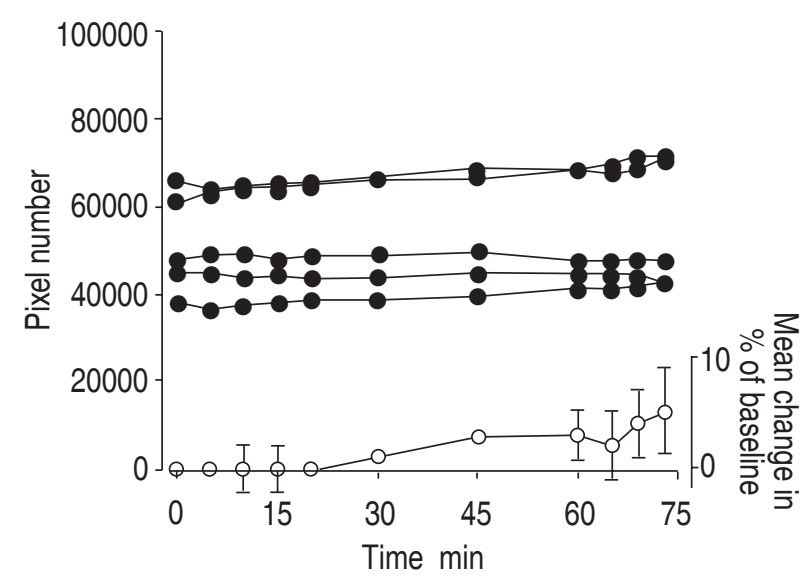

Fig. 2. - Videomicrometric measurements of the cross-sectional area of the same metal ring over time. Data showing the individual measurements of the metal ring at five different occasions expressed as absolute number of pixels ( ). The mean value \pm SEM from these five experiments is expressed as per cent change from baseline $(\bigcirc)$. 


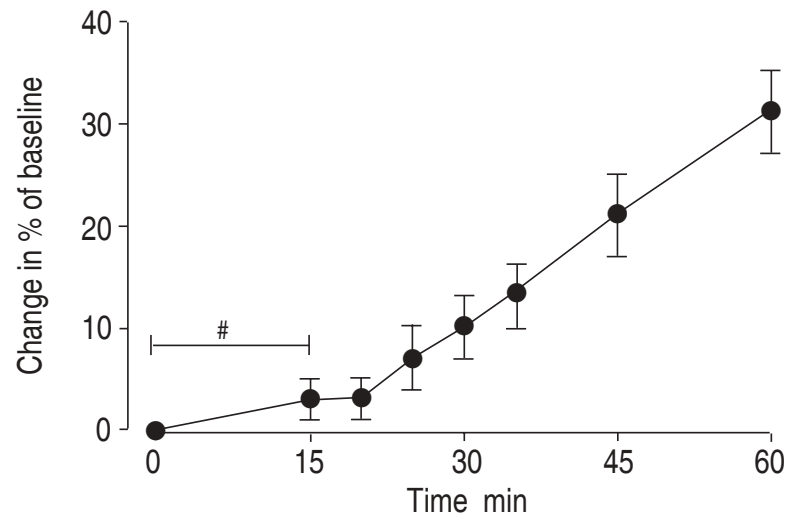

Fig. 3.-Time/course of spontaneous luminal narrowing of airway sections with intact epithelium. Based on these data, "time 0 " of the subsequent experiments was set at 15 min after the first image was taken \#. equilibration period. Data are presented as mean \pm SEM from 21 experiments and expressed as change in luminal area in $\%$ from baseline, i.e. first image recorded.

preparations was significantly reduced at all the measured time points $(p<0.05$; fig. 4). Histological assessment of tissues from which epithelium was abraded confirmed selective removal of the epithelium without damage to underlying layers of the lamina propria or basement membrane in all samples evaluated (results not shown).

\section{Effect of histamine on luminal area}

Addition of $0.1 \mathrm{mM}$ histamine significantly decreased the luminal area in epithelium-intact as well as epithelium-denuded tissues ( $\mathrm{p}<0.05$; fig. 5). Histamineinduced contractions were of similar magnitude in both preparations, irrespective of the spontaneous narrowing observed in the epithelium-intact controls.

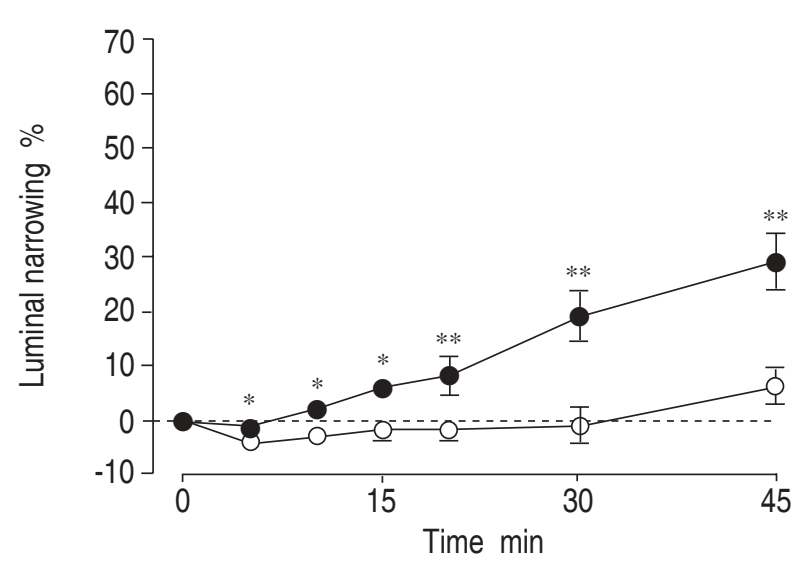

Fig. 4.-Time/course, over a 45-min period, showing that there was a spontaneous narrowing of airway sections with intact epithelium $(\bigcirc)$ that was largely absent in tissues denuded of epithelium (O). Data are presented as mean \pm SEM from six experiments. *: $\mathrm{p}<0.05$; **: $\mathrm{p}<0.01$, compared to epithelium intact preparations, expressed as change in luminal area in $\%$ from time 0 .

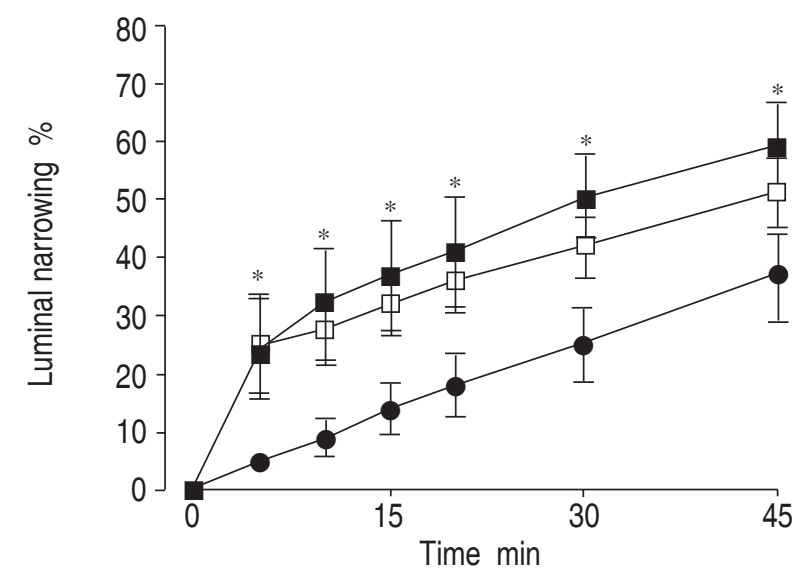

Fig. 5.- Histamine $(100 \mu \mathrm{M})$ caused a significant increase in luminal narrowing ( $\mathbf{\square}$ : epithelium intact, $n=11$ ) beyond the spontaneous narrowing ( $O$ : intact time control, $n=6$ ). Epithelium removal did not affect the narrowing induced by histamine ( $\square$ : epithelium denuded, $n=6$ ). Data are presented as mean $\pm S E M$ from the indicated number of experiments. *: $\mathrm{p}<0.05$, compared to epithelium-intact time controls.

\section{Effect of activated eosinophils on the luminal area}

The tissue samples showed no significant change in narrowing after the addition of $5 \times 10^{5}$ untreated human eosinophils $(30 \pm 7 \%$ at 45 min versus time control $28 \pm 7 \% ; n=11$, whereas stimulation of eosinophils with $1 \mu \mathrm{M}$ PAF led to significant narrowing of bronchial sections in comparison to time controls $(45 \pm 9 \% ; \mathrm{p}=0.01$ versus time control, $\mathrm{p}=0.05$ versus unstimulated cells control; fig. 6). Previous experiments revealed that PAF alone had no effect on the luminal area ( $19 \pm 6 \%$ versus time control $28 \pm 4 \%$; $n=5)$.

Activation of eosinophils was confirmed in parallel experiments measuring $\mathrm{O}_{2} \cdot^{-}$release from PAFactivated and nonactivated eosinophils. Activation of

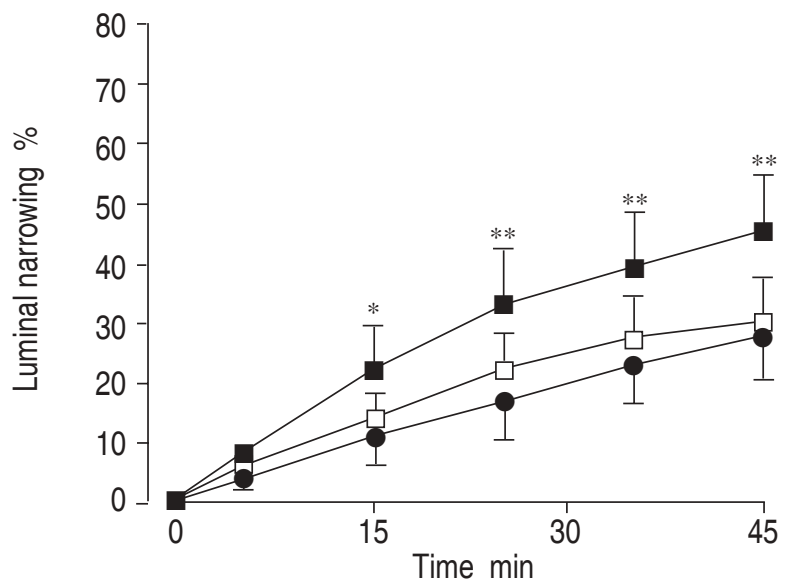

Fig. 6.-Addition of $5 \times 10^{5}$ human eosinophils ( $\square$ ) had no significant effect on airway calibre. When $1 \mu \mathrm{M}$ platelet-activating factor was added to eosinophils, a significant airway narrowing was observed ( $\square$ ). Data are presented as mean \pm SEM from 11 experiments. *: $\mathrm{p}<0.05$; **: $\mathrm{p}<0.01$ compared to matched time control $(\mathbf{O})$ 


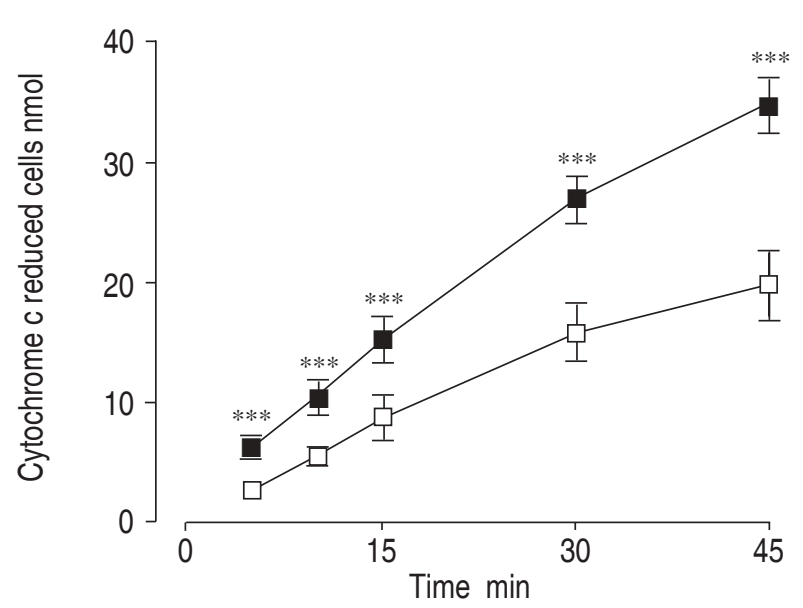

Fig. 7.-Stimulation of human eosinophil respiratory burst by platelet-activating factor (PAF). Cells were pre-incubated at $37^{\circ} \mathrm{C}$ for 10 min prior to addition of PAF ( $\square$ ) or buffer $(\square)$. Superoxide anion generation was measured as the superoxide dismutase inhibited reduction of ferricytochrome c per $10^{5}$ cells in $15 \mathrm{~min}$. Data are presented as mean \pm SEM from 10 experiments. ***: $\mathrm{p}<0.001$ compared to matched time control.

eosinophils led to a time-dependent increase of $\mathrm{O}_{2}{ }^{-}$ production by eosinophils $(\mathrm{p}<0.0001$ for each individual time point; fig. 7).

\section{Effect of passive sensitization on luminal narrowing in response to polyclonal anti-immunoglobulin-E}

Polyclonal anti-IgE, within a concentration range of $1 \mathrm{ng} \cdot \mathrm{ml}^{-1}-10 \mu \mathrm{g} \cdot \mathrm{ml}^{-1}$, led to a concentration-dependent increase in luminal narrowing in passively-sensitized and nonsensitized tissues (fig. 8). Maximal responses in passively-sensitized airway preparations were significantly increased in comparison to the nonsensitized matched controls $(\mathrm{p}<0.05$; fig. 8$)$.

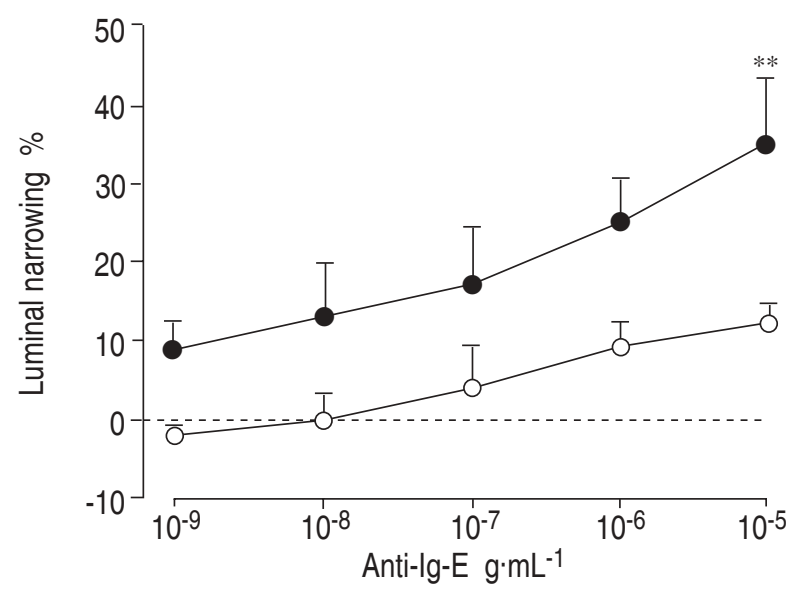

Fig. 8. - Passive sensitization $(\bullet)$ significantly increased concentrationdependent, anti-immunoglobulin (Ig)-E-induced luminal narrowing in bronchial-ring preparations. Data are presented as mean \pm SEM from six experiments. **: $\mathrm{p}<0.01$, compared to nonsensitized, paired controls $(\bigcirc)$.

\section{Discussion}

Computerized videomicrometry is suitable for the study of responses of human airway smooth muscle in vitro. The conditions allow for the utilization of very small quantities of tissues as well as of substances or cells to induce responses in airway preparations. The technique provides the opportunity to study changes in airway calibre in real time under conditions of spontaneous tone, i.e. in the absence of exogenous preload or resting tension, which could be imposed by isometric fixation to force transducers in the organ-bath system.

Although the technique of videomicrometry does not exactly reproduce the in vivo situation, airway smooth muscle contraction in vivo is auxotonic, i.e. an increasing load against which the smooth muscle shortens as the airway narrows [9], so it is a good in vitro approximation of the in vivo situation. Experimental auxotonic measurements can only be performed when changes in length and force are measured simultaneously in a preparation in which the load increases as the muscle shortens. In the present study, bronchial-ring preparations taken from the fifth or sixth generation were dissected free of surrounding alveolar tissue. However, they not only contain smooth muscle, but cartilage and connective tissue. Therefore, within a ring preparation, elastic loads on the smooth muscle cells are present which, in those central and relatively stiff airways, might be of even greater relevance than loads that could be imposed by surrounding alveolar tissue [10].

When using the videomicroscopy system, experimental conditions have to be carefully controlled. The authors' previous videomicroscopy study using guinea-pig airways showed that changes in refraction caused by changes in chamber volume can affect the apparent size of the luminal area [3]. Therefore, it was important to determine the reproducibility of videomicrometric measurements together with the effect of evaporation of microwell volume. Initial experiments using a metal ring in place of bronchial sections demonstrated that measurements of the cross-sectional area performed by videomicrometry are reproducible and not significantly influenced by evaporation over a time period of $60 \mathrm{~min}$, which limited the length of a single experiment to $1 \mathrm{~h}$. However, if the recording period exceeds this, it cannot be excluded that the recorded decrease in cross-sectional area is an artefact caused by evaporation.

A remarkable finding of the study was that using the videomicroscopy system under these near-auxotonic conditions, bronchial rings exhibited a spontaneous narrowing within 60 min that was almost completely absent in epithelium-denuded preparations. The development of spontaneous narrowing was unaffected by the cyclooxygenase inhibitor, indomethacin, ruling out prostanoids as the major mediators. This finding contrasts with the spontaneous, prostanoidmediated luminal narrowing observed in the guinea pig trachea under the same conditions [3] and the absence of spontaneous narrowing of epitheliumintact human airways under isometric conditions in the organ bath [11]. This suggests that human airway 
epithelial cells generate mediators that increase airway tone. One interpretation of the lack of spontaneous airway narrowing in the organ bath is extensive dilution of these mediators through the use of 40-times higher incubation volumes.

In line with observations in the organ bath, histamine induced contractions of the airway microsections with a maximal response after 5-10 min. Following this initial response, a further slow decrease in luminal area was observed, parallel to the spontaneous decrease in the epithelium-intact control tissues. In accordance with guinea pig trachea [3], the histamine-induced airway narrowing under auxotonic conditions was unaffected by cyclooxygenase inhibition and removal of the epithelium, indicating that epithelium-derived factors only contribute to the spontaneous tone and do not influence induced contractions. Together with the previously published data [4], the results indicate that effect and potency of agonists determined by videomicrometry are comparable with the well-characterized effects they evoke in the organ bath.

In contrast with the organ-bath technique, videomicroscopy has the important advantage of small incubation volumes $(250 \mu \mathrm{L}$ for videomicroscopic versus $\sim 10 \mathrm{~mL}$ for organ-bath experiments), thereby allowing investigation of the interaction of airways with factors available only in limited quantities, such as isolated cells. Because eosinophils are believed to play an important role in the pathophysiology of asthma [12], the interaction of human bronchus and isolated eosinophils by videomicrometry was investigated. While unstimulated cells had no significant effect on airway calibre, PAF-activated human eosinophils caused a small but significant narrowing of human bronchial sections, in line with previous data obtained by means of a similar technique [13]. However, in this previous study, effects of eosinophils on airway calibre could not be observed in real time, as cells were placed into bronchial segments, which were then closed at both ends, incubated for $60 \mathrm{~min}$, cut into rings and, thereafter, assessed under a calibrated magnifying lens [13]. Because it is extremely difficult to study cell-mediated airway responses in the large volume of an organ bath, videomicrometric assessment so far appears the most suitable system for this particular purpose.

Passively-sensitized human airways, in which responsiveness to allergen is induced by overnight incubation with IgE-rich serum from atopic individuals, are used as a model for the investigation of airway hyperreactivity and its pharmacological modulation. In a similar manner to organ-bath studies, the assessment of sections of passively-sensitized airways by videomicrometry demonstrated an increase in responsiveness to polyclonal anti-IgE compared with nonsensitized controls. In the future this experimental set-up could provide information about sensitizations impact upon the release and effect of endogenouslyreleased mediators.

In conclusion, the data in the present study demonstrated that, in physiological and pharmacological in vitro studies, responses of small amounts of human airways can be assessed by a videomicroscopy system. Under these conditions, human bronchi exhibit a spontaneous narrowing that is dependent upon the presence of an intact epithelium, but independent of cyclooxygenase metabolites of arachidonic acid. The technique is particularly suitable for studies using very small volumes. This not only allows the investigation of responses to agonist, but interactions with isolated cells, such as eosinophils. It remains to be seen whether videomicrometry can be applied to study not only airway, but also vascular pharmacology.

\section{References}

1. de Jongste JC, van Strik R, Bonta IL, Kerrebijn KF. Measurement of human small airway smooth muscle function in vitro with the bronchiolar strip preparation. J Pharmacol Methods 1985; 14: 111-118.

2. de Jongste JC, Mons H, van Strik R, Bonta IL, Kerrebijn KF. Comparison of isometric and isotonic responses of human small airway smooth muscle in vitro. J Pharmacol Methods 1987; 17: 165-171.

3. Galens S, Muñoz NM, Rabe KF, et al. Assessment of agonist- and cell-mediated responses in airway microsections by computerized videomicrometry. Am J Physiol 1995; 268: L519-L525.

4. Mitchell RW, Rühlmann E, Magnussen $\mathrm{H}$, Muñoz NM, Leff AR, Rabe KF. Conservation of bronchiolar wall area during constriction and dilation of human airways. J Appl Physiol 1997; 82: 954-958.

5. Lebel B, Bousquet J, Chanez P, Barneon G, Morel A, Michel FB, Godard P. Spontaneous and non-specific release of histamine and $\mathrm{PGD}_{2}$ by bronchoalveolar lavage cells from asthmatic and normal subjects: effect of nedocromil sodium. Clin Allergy 1988; 18: 605613.

6. Nowak D, Grimminger F, Jörres R, et al. Increased $\mathrm{LTB}_{4}$ metabolites and $\mathrm{PGD}_{2}$ in $\mathrm{BAL}$ fluid after methacholine challenge in asthmatic subjects. Eur Respir J 1993; 6: 405-412.

7. Dent G, Muñoz NM, Rühlmann E, et al. Protein kinase $\mathrm{C}$ inhibition enhances platelet-activating factorinduced eicosanoid production in human eosinophils. Am J Respir Cell Mol Biol 1998; 18: 136-144.

8. Schmidt D, Rühlmann E, Branscheid D, Magnussen $\mathrm{H}$, Rabe KF. Passive sensitization of human airways increases responsiveness to leukotriene $\mathrm{C}_{4}$. Eur Respir $J$ 1999; 14: 315-319.

9. Moreno RH, Hogg JC, Pare PD. Mechanics of airway narrowing. Am Rev Respir Dis 1986; 133: 1171-1180.

10. Stephens NL, Jiang H. Basic physiology of airway smooth muscle. In: Crystal RG, West JB, eds. The Lung: Scientific Foundations. New York, Raven, 1991; pp. 1087-1115.

11. Watson N, Magnussen H, Rabe KF. Inherent tone of human bronchus: role of eicosanoids and the epithelium. Br J Pharmacol 1997; 121: 1099-1104.

12. Kay AB. Allergy and allergic diseases. $N$ Engl J Med 2001; 344: 30-37.

13. Rabe KF, Muñoz NM, Vita AJ, Morton BE, Magnussen H, Leff AR. Contraction of human bronchial smooth muscle caused by activated human eosinophils. Am J Physiol 1994; 267: L326-L334. 